\title{
Analisis Komparasi Pelaksanaan Klinik Sanitasi antara Puskesmas Pencapaian Tinggi dan Puskesmas Pencapaian Rendah di Kota Jambi Tahun 2018
}

\author{
Fitria Susanti ${ }^{1}$, Yuniar Lestari ${ }^{2}$, Abdiana $^{2}$
}

\begin{abstract}
Abstrak
Pelaksanaan klinik sanitasi dalam kegiatan konseling dan inspeksi lingkungan di Puskesmas Kota Jambi belum mencapai target karenak meningkatnya persentase penyakit berbasis lingkungan. Tujuan: Menganalisis komparasi pelaksanaan klinik sanitasi antara puskesmas pencapaian tinggi dan puskesmas pencapaian rendah di Kota Jambi tahun 2018. Metode: Desain penelitian yang digunakan adalah kualitatif dengan metode wawancara mendalam, FGD dan observasi. Waktu penelitian bulan Maret 2018 sampai April 2019 di Puskesmas Tanjung Pinang, Simpang Kawat, Paal Lima dan Aur Duri. Informan penelitian berjumlah 15 orang dan 32 orang peserta FGD. Hasil: kebijakan klinik sanitasi menunjukkan bahwa tenaga sanitasi puskesmas pencapaian tinggi dan pencapaian rendah belum pernah mendapatkan pelatihan klinik sanitasi. Pada perencanaan anggaran dana puskesmas pencapaian rendah tidak mendapat dana BOK. Perencanaan puskesmas pencapaian tinggi terdapat kegiatan klinik sanitasi sedangkan puskesmas pencapaian rendah tidak ada. Puskesmas pencapaian tinggi telah melaksanakan monitoring dan evaluasi melalui laporan dan lokakarya mini puskesmas, sedangkan puskesmas pencapaian rendah hanya dilakukan melalui laporan. Target yang telah dicapai oleh puskesmas pencapaian tinggi adalah cakupan intervensi lingkungan, sedangkan target yang belum tercapai adalah cakupan konseling dan inspeksi lingkungan. Hal yang sama juga dialami puskesmas pencapaian rendah. Simpulan: Puskesmas pencapaian tinggi perlu meningkatkan komitmen pelaksanaan sedangkan puskesmas pencapaian rendah tidak memberikan beban tugas rangkap.
\end{abstract}

Kata kunci: komparasi, klinik sanitasi, puskesmas

\section{Abstract}

The implementation of the sanitation clinic in the environmental counseling and inspection activities in the Jambi City Health Center had not yet reached its target due to the increasing percentage of environmental-based diseases. Objectives: To analyzed the comparability of the implementation of sanitation clinics between highachieving and low-achieving puskesmas clinics in Jambi City in 2018. Methods: The research design was qualitative with the method of in-depth interviews, FGD and observation. The time of the study was March 2018 to April 2019 at the Tanjung Pinang Health Center, Simpang Kawat, Paal Lima and Aur Duri. The research informants were 15 people and 32 FGD participants. Results: The sanitation clinic policy study showed that the health center sanitation staff achieved high and low achievement had never received sanitation clinic training. In planning the budget for lowachieving Puskesmas funds did not receive BOK funding. Planning for high-achieving puskesmas has sanitation clinic activities while low-achieving health centers do not exist. High-achieving health centers have carried out monitoring and evaluation through health center mini reports and workshops. While low-achieving health centers are only carried out through reports. The target achieved by high achieving puskesmas is the scope of environmental interventions, while the target that has not been achieved is the scope of environmental counseling and inspection. The same is true for low achieving puskesmas. Conclusions: High-achieving health centers need to increase implementation commitment while low-achieving health centers do not provide multiple tasks.

Keywords: comparative, sanitation clinic, health center 
Affiliasi penulis: 1. Dinas Kesehatan Kota Jambi. 2. Bagian IImu Kesehatan Masyarakat Fakultas Kedokteran Universitas Andalas Padang.

Korespondensi: Yuniar Lestari, E-mail: yuyunmadar@gmail.com, Hp: 082376294682

\section{PENDAHULUAN}

Kesehatan lingkungan sebagai salah satu upaya kesehatan bertujuan untuk mewujudkan kualitas lingkungan yang sehat, baik fisik, kimia, biologi, maupun sosial, sehingga memungkinkan setiap orang mencapai derajat kesehatan yang setinggi-tingginya. Terwujudnya kualitas lingkungan sehat di masyarakat melalui penyelenggaraan kesehatan lingkungan telah diatur dalam Peraturan Pemerintah Nomor 66 Tahun 2014 tentang Kesehatan Lingkungan. ${ }^{1}$

Lingkungan dengan kualitas kesehatan yang rendah memicu tingginya angka kejadian penyakit berbasis lingkungan. Pada tahun 2009 Organisasi Kesehatan Dunia (World Health Organizational/WHO) melaporkan bahwa air bersih, sanitasi, dan higienis yang buruk termasuk the leading global risks for burden of disease. Hal ini terjadi terutama di negaranegara dengan tingkat pendapatan rendah (lowincome countries) dimana air bersih, sanitasi, dan higienis merupakan faktor risiko penyebab penyakit diare yang saat itu menduduki urutan keempat dengan jumlah kematian sebanyak 1,6 juta jiwa (6,1\%). Sebagian besar kematian akibat diare di dunia mencapai $88 \%$. Dari jumlah tersebut, sekitar $84 \%$ menimpa anak-anak. ${ }^{2}$

Penyakit berbasis lingkungan seperti DBD, malaria, dan diare masih mendominasi di Indonesia dan memerlukan perhatian serius. Berdasarkan laporan Dinas Kesehatan Provinsi Jambi Tahun 2017, penyakit berbasis lingkungan masih termasuk ke dalam kategori sepuluh penyakit terbesar dengan jumlah penderita ISPA sebesar $45,38 \%$ dan diare sebesar 28,3\%. Di samping itu Provinsi Jambi hingga saat ini masih menjadi salah satu provinsi endemis penyakit DBD. Pada tahun 2016-2017 terjadi peningkatan penyakit DBD dengan tingkat kejadian 44,90\% per 100.000 penduduk dan angka kematian $0,31 \%{ }^{3}$
Berdasarkan data dari Dinas Kesehatan Kota Jambi bahwa pada tahun 2015-2017 penyakit berbasis lingkungan di Kota Jambi masuk kategori sepuluh penyakit terbesar. Tren kasus ISPA dari tahun 20152017 menunjukkan fluktuasi jumlah penderita. Hal tersebut terlihat bahwa pada tahun 2015-2016 kasus ISPA mengalami penurunan sebesar 2,40\%, sedangkan pada tahun 2016-2017 terjadi peningkatan sebesar $1,45 \%$. Hal yang sama juga terjadi pada kasus diare. Pada tahun 2015-2016 jumlah kasus diare mengalami penurunan $0,56 \%$, sedangkan pada tahun 2016-2017 terjadi peningkatan kasus sebesar 0,32\%. Tren penyakit DBD pada tahun 2015 terjadi peningkatan dengan tingkat kejadian sebesar $80,7 \%$ per 100.000 penduduk dan angka kematian 14\%. Namun, terjadi penurunan pada tahun 2016 dengan tingkat kejadian sebesar $27 \%$ per 100.000 penduduk dan angka kematian 0\%. Pada tahun 2017 kembali terjadi peningkatan dengan tingkat kejadian sebesar 84\% per 100.000 penduduk dan angka kematian $1,2 \%{ }^{4}$

Pelayanan klinik sanitasi merupakan implementasi Permenkes RI Nomor 13 Tahun 2015. Kegiatan klinik sanitasi adalah upaya mengintegrasikan antara pelayanan kesehatan promotif, preventif, dan kuratif yang difokuskan pada penduduk yang berisiko tinggi untuk mengatasi masalah penyakit berbasis lingkungan yang dilaksanakan oleh petugas bersama masyarakat, baik di dalam maupun di luar puskesmas. Beberapa penelitian tentang klinik sanitasi, telah banyak dilakukan. $^{5}$

Data pencapaian hasil klinik sanitasi yang dikeluarkan oleh Dinas Kesehatan Kota Jambi dan hasil wawancara awal dengan Kepala Seksi Kesehatan Lingkungan Kerja dan Olah Raga, diketahui bahwa klinik sanitasi yang ada di puskesmas sudah berjalan dari tahun 2005 sampai dengan tahun 2018. Namun, cakupan pencapaian pelaksanaan konseling dan inspeksi lingkungan hasilnya belum mencapai target. Sebaliknya, cakupan pencapaian pelaksanaan intervensi lingkungan telah mencapai target. Hal ini dapat dilihat dari hasil pencapaian pelaksanaan konseling hanya sebesar $11,70 \%$, 
sedangkan target yang harus dicapai sebesar 29,70\%. Hasil pelaksanaan inspeksi lingkungan sebesar $43,38 \%$ dari target yang harus dicapai sebesar $100 \%$. Pelaksanaan intervensi lingkungan sudah sesuai dengan target yang harus dicapai, yaitu sebesar $100 \%{ }^{4}$

Berdasarkan pemaparan di atas, maka perlu dianalisis komparasi pelaksanaan klinik sanitasi antara puskesmas pencapaian tinggi dan puskesmas pencapaian rendah di Kota Jambi tahun 2018. Penelitian ini menggunakan pendekatan sistem yang meliputi aspek input, proses, dan output.

\section{METODE}

Penelitian ini menggunakan metode kualitatif melalui pendekatan komparasi yang bertujuan untuk membandingkan pelaksanaan klinik sanitasi antara puskesmas pencapaian tinggi dan puskesmas pencapaian rendah di Kota Jambi tahun 2018 dengan metode wawancara mendalam, Focus Group Discussion (FGD), observasi dan telaah dokumen. ${ }^{6}$

Waktu penelitian mulai dari bulan Maret 2018 sampai April 2019. Lokasi penelitian ditentukan berdasarkan kriteria-kriteria sesuai dengan tujuan penelitian yaitu yang mewakili kelompok puskesmas dengan hasil pencapaian tinggi klinik sanitasi adalah Puskesmas Tanjung Pinang dan Puskesmas Simpang Kawat, sedangkan yang mewakili kelompok puskesmas dengan hasil pencapaian rendah adalah Puskesmas Paal Lima dan Puskesmas Aur Duri.

Sampel penelitian berperan sebagai narasumber, partisipan dan informan. Informan dalam penelitian ini adalah Kepala Seksi Kesehatan Lingkungan, Kesehatan kerja dan Olahraga Dinas Kesehatan Kota Jambi, Kepala Puskesmas Tanjung Pinang, Puskesmas Paal Lima, Puskesmas Simpang Kawat dan Puskesmas Aur Duri, pemegang program kesehatan lingkungan Puskesmas Tanjung Pinang, Puskesmas Paal Lima, Puskesmas Simpang Kawat dan Puskesmas Aur Duri, tenaga dokter poliklinik Puskesmas Tanjung Pinang, Puskesmas Paal Lima, Puskesmas Simpang Kawat dan Puskesmas Aur Duri. Sedangkan informan untuk FGD adalah pasien yang berkunjung ke klinik sanitasi di Puskesmas Tanjung Pinang, Puskesmas Paal Lima, Puskesmas Simpang Kawat dan Puskesmas Aur Duri.
HASIL

\section{Komponen Input}

a. Kebijakan

Kebijakan yang dipakai puskesmas pencapaian tinggi dan puskesmas pencapaian rendah dalam pelaksanaan klinik sanitasi mengacu kepada Permenkes Nomor 13 Tahun 2015 dan buku pedoman pelaksanan klinik sanitasi. Puskesmas pencapaian tinggi telah mensosialisasikan klinik sanitasi pada petugas puskesmas sedangkan puskesmas pencapaian rendah belum mensosialisasikannya kepada seluruh petugas puskesmas. ${ }^{5}$

\section{b. Tenaga}

Tenaga klinik sanitasi di Puskesmas Pencapaian Tinggi dan Puskesmas Pencapaian Rendah sudah mengacu kepada Permenkes No. 75 tahun 2014 yaitu satu satu orang petugas sanitasi untuk satu puskesmas, latar belakang pendidikan petugas klinik pada puskesmas pencapaian tinggi juga telah sesuai yaitu D-3 Kesehatan Lingkungan sedangkan pada puskesmas pencapaian rendah petugas kliniknya masih berlatarbelakang pendidikan D-1 Kesehatan Lingkungan. Pembinaan dari dinas dan puskesmas masih kurang. Untuk pelatihan baik petugas di puskesmas pencapaian tinggi ataupun di puskesmas pencapaian rendah sama-sama belum pernah mendapatkan, karena Dinas Kesehatan belum pernah mengadakan pelatihan khusus klinik sanitasi. ${ }^{7}$

\section{c. Metode}

Metode dalam pelaksanaan klinik sanitasi di puskesmas dengan pencapaian tinggi telah sesuai dengan buku pedoman klinik sanitasi yaitu konseling, inspeksi lingkungan dan intervensi lingkungan telah dijalankan sedangkan di puskesmas pencapaian rendah metode yang dijalankan rutin hanya konseling, untuk inspeksi dan intervensi dilaksanakan bila diperlukan saja. ${ }^{8}$

d. Dana

Dinas Kesehatan Kota Jambi tidak mengganggarkan dana untuk kegiatan klinik sanitasi. Pada puskesmas pencapaian tinggi sudah menganggarkan kegiatan klinik sanitasi dalam anggaran BOK, sedangkan pada puskesmas 
pencapaian rendah belum menganggarkan dan lebih memprioritaskan kegiatan kesling lainnya.

\section{e. Sarana dan Prasarana}

Kelengkapan sarana dalam pelaksanaan klinik sanitasi di puskesmas dengan pencapaian tinggi sudah lengkap yaitu memiliki ruang klinik sanitasi, sanitarian kit, media promosi, buku pedoman dan formulir wawancara. Kendaraan tidak ada, tetapi petugas memakai kendaraan pribadi karena Dinkes tidak ada pengadaan kendaraan operasional klinik sanitasi, sedangkan pada puskesmas pencapaian rendah masih sangat kurang karena tidak memiliki ruang klinik sanitasi, tidak mempunyai sanitarian kit dan media promosi karena keterbasan anggaran dana yang dimiliki puskesmas. ${ }^{9}$

\section{Komponen Proses}

\section{a. Perencanaan}

Perencanaan dalam pelaksanaan klinik sanitasi di puskesmas pencapaian tinggi sudah disusun dalam POA kesehatan lingkungan berdasarkan permintaan masyarakat dan lintas program dengan mekanisme penyusunan perencanaan, sehingga perencanan yang dibuat sudah baik dan tepat sasaran. Sedangkan pada puskesmas pencapaian rendah belum memasukkan kegiatan klinik sanitasi pada POA kesling puskesmas, karena pimpinan dan petugas belum menjadikan klinik sanitasi sebagai kegiatan prioritas sehingga belum dijadikan komitmen dalam perencanaan. ${ }^{10}$

\section{b. Pengorganisasian}

Pengorganisasian dalam pelaksanaan klinik sanitasi di Puskesmas pencapaian tinggi sudah tersusun dalam bentuk struktur organisasi dan uraian tugas klinik sanitasi sedangkan pada Puskesmas pencapaian rendah belum ada. ${ }^{11}$

\section{c. Pelaksanaan}

Pelaksanaan klinik sanitasi di Puskesmas pencapaian tinggi sudah sesuai dengan buku pedoman. Jadwal buka dari hari Senin sampai Sabtu dengan mengikuti alur pelayanan diawali dengan kunjungan pasien ke klinik dan diberi rujukan ke klinik sanitasi untuk mendapatkan konseling, inspeksi lingkungan dan intervensi lingkungan terhadap penyakit berbasis lingkungan. Sedangkan puskesmas pencapaian rendah belum sesuai dengan buku pedoman dilihat dari jadwal buka 2 hari seminggu, lupa merujuk, inspeksi lingkungan dan intervensi lingkungan dilakukan bila diperlukan. ${ }^{12}$

\section{d. Monitoring dan Evaluasi}

Mengenai monitoring dan evaluasi dalam pelaksanaan klinik sanitasi dari Dinas Kesehatan Kota Jambi ke puskesmas tidak dilakukan karena tidak ada dana pembinaan klinik sanitasi. Di Puskesmas pencapaian tinggi monitoring dan evaluasi dilakukan melalui laporan bulanan dan lokakarya mini puskesmas. Sedangkan di puskesmas capaian rendah, monitoring dan evaluasi dilaksanakan melalui laporan dan tidak ada notulen lokakarya mini puskesmas yang membahas klinik sanitasi karena kurangnya pemahaman Kepala Puskesmas bagaimana seharusnya mekanisme monev yang dilakukan terhadap pelaksanaan klinik sanitasi. ${ }^{13}$

\section{Komponen Output}

Output dalam pelaksanaan klinik sanitasi di puskesmas pencapaian tinggi untuk cakupan konseling sebesar 19,32\% dan $11,05 \%$ belum mencapai target yang diharapkan $(31,33 \%$ dan $21,56 \%$ ) dan cakupan inspeksi lingkungan sebesar $72,41 \%$ dan $70,33 \%$ belum mencapai target yang diharapkan sebesar $100 \%$. Sedangkan Output dalam pelaksanaan klinik sanitasi di puskesmas pencapaian rendah belum mencapai target yang diharapkan terlihat dari cakupan klinik sanitasi. ${ }^{3}$

\section{PEMBAHASAN}

\section{Komponen Input}

a. Kebijakan

Kebijakan dalam pelaksanaan klinik sanitasi di puskesmas diatur dalam Permenkes RI Nomor 13 Tahun 2015 tentang Penyelenggaraan Pelayanan Kesehatan Lingkungan di Puskesmas. Pada puskesmas pencapaian tinggi kebijakan tidak menjadi permasalahan karena kebijakan telah tersosialisasikan dengan baik kepada petugas di puskesmas dan puskesmas ini menjadikan klinik sanitasi sebagai salah satu kegiatan prioritas. Pimpinan puskesmas paham jika klinik sanitasi sangat penting untuk 
dilaksanakan sehingga pimpinan puskesmas mengintruksikan kepada semua petugas untuk berkomitmen menjalankan klinik sanitasi sesuai kebijakan yang berlaku. $^{5}$

Hal berbeda justru terjadi pada puskesmas pencapaian rendah dimana kebijakan tidak disosialisasikan sampai ke petugas. Hal ini disebabkan karena pimpinan tidak mengetahui jika kebijakan tersebut harus disosialisasikan, disamping itu kebijakan tidak menjadi prioritas karena puskesmas lebih mengutamakan kegiatan kesling lainnya seperti TPM dan TTU. Tentunya konidisi ini akan berdampak kepada rendahnya pemahaman pelaksana kebijakan yakni petugas pelaksana klinik sanitasi terhadap kebijakan klinik sanitasi yang telah dituangkan dalam Permenkes Nomor 13 Tahun 2015, sehingga pelaksanaan klinik sanitasi tidak sesuai dengan standar yang ditetapkan oleh permenkes. Untuk itu sangat perlu penyampaian kebijakan yang ada kepada pelaksana kebijakan melalui bentuk sosialisasi. ${ }^{5}$

Dinas Kesehatan juga perlu membuat suatu kebijakan untuk menguatkan komitmen seluruh tenaga kesehatan yang terlibat dalam pelaksanaan klinik sanitasi berupa aturan tentang mekanisme pelaksanaan klinik sanitasi yang tetap mengacu kepada Permenkes Nomor 13 Tahun 2015, kebijakan yang dibuat disesuaikan dengan kondisi dan kebutuhan puskesmas dibawah Dinas Kesehatan Kota Jambi. Setelah kebijakan dibuat langsung disosialisasikan untuk menyamakan persepsi disemua puskesmas sehingga tujuan pelaksanaan klinik sanitasi di Kota Jambi dapat tercapai. ${ }^{5}$

Penguatkan pelaksanaan klinik sanitasi selain kebijakan yang dibuat oleh Kepala Dinas Kesehatan, masing-masing puskesmas juga mestinya membuat kebijakan internal untuk membuat komitmen tertulis berupa himbauan pada semua staf puskesmas yang terlibat untuk benar-benar melaksanakan kegiatan klinik sanitasi, sehingga semua staf yang terlibat dengan pelaksanaan klinik sanitasi di puskesmas benar-benar merasa ikut bertanggung jawab melaksanakan klinik sanitasi dan mencapai tujuan dari pelaksanaan klinik sanitasi tersebut. ${ }^{14}$

\section{b. Tenaga}

Ketersediaan jumlah tenaga di puskesmas pencapaian tinggi sudah mencukupi, yaitu 2 (dua) orang. Hal ini sudah sesuai dengan Permenkes RI Nomor 75 Tahun 2014 tentang Puskesmas. ${ }^{7}$ Dalam Permenkes $\mathrm{RI}$ tersebut dijelaskan bahwa rasio satu orang tenaga sanitasi untuk satu puskesmas. Selain itu, latar belakang pendidikan tenaga sanitasi adalah Diploma 3 (D-3) Kesehatan Lingkungan dan petugas tidak merangkap jabatan. Hal ini diperkuat dengan diberlakukannya Permenkes RI Nomor 13 Tahun 2015 yang menjelaskan bahwa pelayanan lingkungan dilakukan oleh tenaga sanitasi dengan latar belakang pendidikan D-3 Kesehatan Lingkungan dan tidak boleh merangkap jabatan. ${ }^{5}$ Dengan telah terpenuhinya kebutuhan tenaga pada Puskesmas ini membuat pimpinan bisa menempatkan petugas sesuai dengan tugas dan fungsinya masing-masing, begitu juga dengan tenaga sanitarian hanya bertanggung jawab untuk kegiatan kesling dan kegiatan klinik sanitasi. ${ }^{4}$

Puskesmas pencapaian rendah bertentangan dengan isi Permenkes RI Nomor 13 Tahun 2015. Memang bila dilihat dari jumlah, ketersediaan tenaga sudah mencukupi. Namun, tenaga sanitasi tersebut berlatar belakang pendidikan Diploma 1 (D-1) Kesehatan Lingkungan dan merangkap jabatan di bagian administrasi. Hal ini disebabkan jumlah tenaga puskesmas cukup tetapi tenaga administrasi yang masih kurang dan minimnya pemahaman tugas pokok dan fungsi. Petugas sanitasi, baik puskesmas pencapaian tinggi maupun pencapaian rendah, belum mendapatkan pelatihan klinik sanitasi. $\mathrm{Hal}$ ini disebabkan karena Dinas Kesehatan Kota belum mengadakan kegiatan pelatihan yang di adakan di tingkat Kota. $^{5}$

Permasalahan tenaga pelaksana klinik sanitasi yang masih kurang dari kualitas adalah tidak adanya pembinaan dari dinas kesehatan ke puskesmas yang disebabkan tidak adanya dana pembinaan, petugas masih tamatan D1 Kesling karena kurangnya minat petugas untuk melanjutkan pendidikan dan dana untuk sekolah juga tidak ada. Petugas juga belum pernah mendapat pelatihan karena Dinas Kesehatan belum 
pernah mengadakan pelatihan klinik sanitasi dengan alasan tidak adanya dana pelatihan.

Permasalahan beban kerja rangkap diatasi dengan mengkaji ulang tentang pembagian tugas di puskesmas dengan terlebih dahulu melakukan analisis jabatan untuk perencanaan penempatan petugas. Jika memang beban kerja yang tinggi sehingga puskesmas benar-benar mengetahui kebutuhan tenaganya, seharusnya tenaga sanitasi tidak dibebankan dengan pekerjaan lain, mengingat tugas pokok dari tenaga sanitasi tersebut sudah cukup banyak mencakup kegiatan dalam dan luar gedung. Dari hasil analisis jabatan yang dilakukan, jika memang ada kekurangan tenaga dipuskesmas selanjutnya dapat mengajukan usulan ke Dinas Kesehatan untuk menambah tenaga dengan dasar dan data yang jelas, sehingga tenaga yang diusulkan benar-benar seusai dengan kebutuhan. $^{15}$

\section{c. Metode}

Metode pelaksanaan klinik sanitasi di puskesmas pencapaian tinggi sudah cukup baik karena sudah menerapkan identifikasi penyakit, konseling, jadwal kunjungan rumah serta sudah melakukan kegiatan inspeksi lingkungan dan intervensi lingkungan untuk kegiatan luar gedung, ini menunjukkan jika tenaga sanitarian sudah memahami metode pelaksanaan klinik sanitasi sesuai dengan pedoman yang dikeluarkan Kemenkes, peran pimpinan dalam mensosialisasikan kebijakan dan pedoman, sehingga petugas benar-benar memahami Standar Prosedur Operasional (SPO) yang mesti dijalankan. Sedangkan puskesmas pecapaian rendah metode pelaksanaan kegiatan klinik sanitasi belum optimal karena hanya baru melaksanakan kegiatan konseling yang merupakan bagian dari metode pelaksanaan klinik sanitasi dalam gedung, jadwal kunjungan luar gedung sebagai tindak lanjut konseling, dan untuk kegiatan luar gedung melalui metode inspeksi dan intervensi lingkungan dilaksanakan bila diperlukan. ${ }^{15}$

Metode yang dijalankan pada puskesmas pencapaian rendah masih terfokus pada kegiatan dalam gedung sedangkan metode luar gedung dilaksanakan bila diperlukan saja, hal ini disebabkan petugas mempunyai beban tugas rangkap, sehingga bukan hanya bertanggung jawab terhadap pelaksanaan kegiatan klinik sanitasi tetapi juga bertanggung jawab dengan kegiatan atau program puskesmas lainnya, kurangnya tenaga di administrasi yang membuat pimpinan mengambil kebijakan untuk memberikan tugas rangkap dengan tujuan memberdayakan tenaga yang ada, namun hal tersebut justru membuat petugas mengabaikan tugas luar gedung kegiatan klinik sanitasi.

Penyebab lain petugas hanya melaksanakan kegiatan metode luar gedung bila diperlukan saja adalah pemahaman petugas kurang terhadap metode yaitu SPO pelaksanaan klinik sanitasi, hal ini disebabkan petugas belum pernah mendapatkan pelatihan khusus klinik sanitasi dan belum pernah mendapat pembinaan dari kepala puskesmas ataupun Dinas Kesehatan. Sementara itu metode berbeda dalam pelaksaaan klinik sanitasi di puskesmas yang ada di Bukit Tinggi dan Kabupaten Bantul adalah melalui kunjungan ke rumah warga, kerja sama lintas program, kerjasama lintas sektor dan evaluasi. Semua metode ini telah dilaksanakan dengan hasil baik. ${ }^{2}$

d. Dana

Dinas Kesehatan Kota Jambi tidak mengusulkan dan mengganggarkan dana untuk kegiatan klinik sanitasi. Hal ini disebabkan Dinas Kesehatan Kota Jambi beranggapan bahwa puskesmas dapat memanfaatkan dana Bantuan Operasional Kesehatan (BOK). Dana kegiatan klinik sanitasi diusulkan sesuai dengan perencanaan kegiatan klinik sanitasi, tenaga sanitasi mengetahui pentingnya kegiatan klinik sanitasi sehingga memasukkan kegiatan klinik sanitasi dalam penganggaran BOK (Bantuan Operasional Kesehatan) Puskesmas. Dana yang dianggarkan oleh Puskesmas Tanjung Pinang dan Puskesmas Simpang Kawat cukup tinggi, sehingga kegiatan dapat berjalan karena didukung dana yang memadai, dan pada realisasinya sebesar $100 \%$ yang sudah dialokasikan benar-benar terpakai untuk pelaksanaan klinik sanitasi. ${ }^{16}$

Hal ini berbeda dengan dana di puskesmas pencapaian rendah. Dana BOK tidak diusulkan dan dianggarkan khusus untuk kegiatan klinik sanitasi (anggaran untuk program kesehatan lingkungan). Hal ini disebabkan pada saat turun ke lapangan kegiatan 
klinik sanitasi bersamaan dengan program lain, seperti program promkes, TB paru, dan diare. Puskesmas lebih memprioritaskan kegiatan kesehatan lingkungan yang lain, seperti Sanitasi Total Berbasis Masyarakat (STMB), Tempat-Tempat Umum (TTU), dan Tempat Pengolahan Makanan (TPM). Yang menjadi alasan puskesmas memprioritaskan kegiatan ini adalah di wilayah kerjanya jumlah TPM dan TTU sangat banyak (lebih dari 158 tempat), sedangkan kunjungan pasien ke klinik sanitasi sangat rendah.

Berdasarkan perbedaan alokasi dana seharusnya puskesmas pencapaian rendah bisa mengusulkan dan mulai menganggarkan di tahuntahun yang akan datang semua kegiatan yang berhubungan dengan klinik sanitasi bersumber dana BOK dan disesuaikan dengan kebutuhan dan rencana kegiatan klinik sanitasi pada tahun tersebut. Tidak ada alasan masalah dana lagi bagi petugas untuk tidak melaksanakan semua kegiatan. Pimpinan puskesmas pencapaian rendah mestinya juga menyetujui usulan penganggaran dana untuk kegiatan klinik sanitasi dan menjadikan kegiatan klinik sanitasi menjadi kegiatan atau program prioritas di puskesmas, sehingga tujuan pelaksanaan dan pencapaian target kegiatan klinik sanitasi dapat terpenuhi.

\section{e. Sarana dan Prasarana}

Sarana dan prasarana pada puskesmas pencapaian tinggi sudah memenuhi standar karena sudah memiliki ruang klinik sanitasi, sanitarian kit yang lengkap dan media promosi yang sudah tersedia, hal ini disebabkan komitmen pimpinan terhadap pelaksanaan klinik sanitasi tinggi, sehingga menyediakan satu ruangan yang ada di puskesmas sebagai ruang pojok sanitasi, dan menyediakan anggaran BOK untuk pembelian sanitarian kit serta pengadaan media promosi, permasalahan sarana yang masih kurang dipuskesmas pencapaian tinggi adalah belum ada kendaraan operasional sehingga menjadi kendala saat petugas turun kelapangan. ${ }^{16}$

Hal berbeda justru terlihat di puskesmas pencapaian rendah yang sarana dan prasarananya kurang, mestinya pimpinan puskesmas pencapaian rendah mulai mengalokasikan dana untuk pengadaan sarana klinik sanitasi dan jika dana puskesmas belum mencukupi untuk memenuhi sarana dan prasarana tersebut, pimpinan puskesmas bisa mengusulkan ke Dinas Kesehatan Kota Jambi untuk bisa memfasilitasi dukungan dana untuk pengadaan sarana atau prasarana klinik sanitasi. $^{9}$

\section{Komponen Proses}

\section{a. Perencanaan}

Puskesmas pencapaian tinggi telah menyusun perencanaan kegiatan klinik sanitasi dalam plan of action (POA) kesehatan lingkungan karena pada puskesmas pencapaian tinggi kegiatan klinik sanitasi merupakan kegiatan yang wajib dilaksanakan. Perencanaan di susun sesuai permintaan masyarakat dengan mekanisme penyusunan perencanaan berdasarkan kebutuhan yang diajukan oleh tiap pemegang program kerja yang dilaksanakan secara terpadu dengan lintas program. Perencanaan yang dibuat mencakup kegiatan, waktu pelaksanaan, sumber dana dan penanggung jawab kegiatan. Hal ini berbeda dengan puskesmas pencapaian rendah. Perencanaan yang disusun dalam bentuk POA kesehatan lingkungan memang diajukan oleh tenaga sanitasi kepada kepala puskesmas. Didalamnya tidak menyebutkan kegiatan klinik sanitasi. Yang dicantumkan adalah Kegiatan Sanitasi Total Berbasis Masyarakat (STBM), Tempat-Tempat Umum (TTU), dan Tempat Pengolahan Makanan (TPM). Hal ini disebabkan kegiatan klinik sanitasi belum menjadi kegiatan prioritas puskesmas. ${ }^{10}$

Perencanaan kegiatan klinik sanitasi pada puskesmas pencapaian rendah tidak ada disebabkan perencanaan klinik sanitasi memang tidak dimasukkan kedalam POA karena memprioritas kegiatan kesling yang lain. Disamping itu penyebab lainnya adalah komitmen dari pimpinan dan petugas sangat kurang terhadap perencanaan klinik sanitasi hal ini disebabkan tidak menjadi prioritas, sehingga puskesmas merasa tidak perlu membuat perencanaan

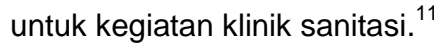

Perencanaan klinik sanitasi di puskesmas seharusnya dimulai dengan melakukan pengumpulan data dan identifikasi masalah meliputi data pencapaian klinik sanitasi tahun sebelumnya, hasil umpan balik dari masyarakat, survei, pertemuan, keluhan atau pengaduan. Selanjutnya melakukan analisis masalah terhadap hasil identifikasi masalah yang telah 
didapatkan, analisis masalah dilakukan oleh sanitarian, analisa masalah menggunakan diagram tulang ikan atau Analisis Akar Masalah (AAM) dan pemilihan pemecahan masalah menggunakan metode Urgency Seriousness Growth (USG) atau Multiple Criteria Utility Assessment (MCUA). Tahap berikutnya adalah melakukan penyusunan Rencana Usulan Kegiatan (RUK) berdasarkan pemecahan masalah dan terakhir pada perencanaan adalah penyusunan Rencana Pelaksana Kegiatan (RPK), dibuat berdasarkan alokasi dana yang telah disetujui puskesmas dengan memperhatikan RUK yang telah disusun tahun sebelumnya, penyusunan RPK dilaksanakan bersama-sama melalui pertemuan koordinasi lintas program di puskesmas. ${ }^{17}$

Puskesmas dalam membuat perencanaan kesehatan lingkungan di dalamnya harus terdapat kegiatan klinik sanitasi yang dilakukan berdasarkan kebutuhan yang disusun bersama-sama, baik dari lintas program maupun lintas sektor. Perencanaan disusun berdasarkan kemampuan menjalankan dan kecukupan anggaran yang sejalan dengan visi dan misi puskesmas, pada khususnya dan Dinas Kesehatan pada umumnya. Perencanaan yang dibuat mencakup kegiatan, waktu pelaksanaan, sumber dana dan penanggung jawab kegiatan. Perencanaan kegiatan yang dibuat adalah perencanaan yang benarbenar terukur, dapat dilaksanakan dan tepat sasaran untuk menyelesaikan permasalahan sanitasi di puskesmas. Keberhasilan suatu program juga dipengaruhi oleh perencanaan yang tepat dan pada saat evaluasi dilakukan semua yang direncanakan benar-benar telah dilaksanakan dengan baik.

\section{b. Pengorganisasian}

Pengorganisasian kegiatan pelaksanaan klinik sanitasi pada puskesmas pencapaian tinggi sudah ada, baik itu dalam struktur organisasi klinik sanitasi maupun dalam uraian tugas dan tanggung jawab karena pimpinan dan petugas sanitasi tahu pentingnya dibuat struktur organisasi dan uraian tugas masing-masing petugas yang terlibat. Hal ini berbeda dengan puskesmas pencapaian rendah yang menunjukkan bahwa pengorganisasian kegiatan pelaksanaan klinik sanitasi dalam bentuk strukur organisasi dan uraian tugas belum ada, tetapi pengoganisasiannya terintegrasi dengan struktur organisasi puskesmas. Hal ini disebabkan kepala puskesmas dan tenaga sanitasi tidak mengetahui jika harus membuat struktur klinik sanitasi. Jika struktur organisasi puskesmas pencapaian rendah tidak ada karena pimpinan dan petugas tidak mengetahui jika harus ada struktur organisasi pelaksanaan klinik sanitasi di puskesmas, hal ini juga disebabkan oleh tidak ada pembinaan yang dilakukan ke puskesmas tentang bagaimana seharusnya manajemen pelaksanaan klinik sanitasi puskesmas. ${ }^{15}$

Penegasan penanggung jawab dan pihak-pihak yang terlibat dalam pelaksanaan klinik sanitasi mestinya puskesmas membuat struktur organisasi klinik sanitasi di puskesmas yang dimulai dari pimpinan sebagai top manjemen di puskesmas ditambah dengan semua staf puskesmas yang terlibat dalam pelaksanaan klinik sanitasi. Struktur organisasi dibuat diikuti dengan penjelasan uraian tugas dan tanggung jawab, sehingga semua komponen yang terlibat dalam struktur organisasi benar-benar tahu dan paham apa yang menjadi tugas dan kewajibannya dalam pelaksanaan klinik sanitasi.

\section{c. Pelaksanaan}

Puskesmas pencapaian tinggi dalam pelaksanaan klinik sanitasi sudah sesuai dengan buku pedoman dan SPO, karena semua petugas dan tenaga sanitasi sudah paham tentang alur dan metode pelaksanaan klinik sanitasi. Jadwal klinik sanitasi di buka setiap hari. Alur pelayanan diawali dengan pasien yang berasal dari poliklinik, poli kesehatan ibu dan anak (KIA), dan poli lanjut usia. Pasien yang menderita penyakit berbasis lingkungan, antara lain Infeksi Saluran Pernafasan Akut (ISPA), diare, Demam Berdarah Dengue (DBD), malaria, dan tuberkulosis (TBC), akan dirujuk ke klinik sanitasi untuk diberi konseling. Selanjutnya, akan dilakukan inspeksi lingkungan dan intervensi lingkungan. Intervensi lingkungan hanya berupa pemberian Komunikasi, Informasi dan Edukasi (KIE) tanpa melakukan perbaikan pembangunan sarana, pengembangan teknologi tepat guna dan rekayasa lingkungan. Hal ini disebabkan tidak tersedianya dana untuk melaksanakan kegiatan fisik dan juga tidak ada kerja sama lintas sektor. ${ }^{12}$ 
Hal ini berbeda dengan yang ada di puskesmas pencapaian rendah pelaksanaan klinik sanitasi belum sesuai dengan buku pedoman dan SPO. Hal ini disebabkan masih kurangnya pemahaman tenaga sanitasi yang terkait dengan kegiatan klinik sanitasi untuk menjalankan SPO. Klinik hanya dibuka dua hari dalam seminggu karena petugas merangkap jabatan. Kegiatan klinik sanitasi dimulai dengan konseling penyakit berbasis lingkungan. Apabila diperlukan, inspeksi lingkungan dan intervensi lingkungan barulah dilakukan. Hal ini disebabkan karena puskesmas tidak tersedia dana klinik sanitasi, pada saat turun ke lapangan bersama sama dengan program kegiatan lain dan tidak ada kerja sama lintas sektor. ${ }^{13}$

Kendala yang dihadapi saat pelaksanaan klinik sanitasi di puskesmas pencapaian tinggi adalah pada kegiatan konseling dari poliklinik yang lupa merujuk pasien karena kurangnya komitmen dari petugas poliklinik untuk dapat melaksanakan kegiatan klinik sanitasi sesuai SPO. Ruang klinik sanitasi berada diatas apabila pasien usia lanjut susah untuk naik ke atas dan inspeksi lingkungan tidak memiliki kendaraan tetapi menggunakan kendaraan pribadi. Kendala yang dihadapi puskesmas pencapaian rendah dalam pelaksanaan klinik sanitasi, yaitu kegiatan konseling dari poliklinik yang lupa merujuk pasien, jadwal buka hanya dua kali seminggu karena tenaga sanitasi merangkap jabatan dan tidak mempunyai ruangan klinik. Pada kegiatan inspeksi lingkungan, kendala yang dihadapi adalah tidak tersedianya dana dan kendaraan operasional. Kendala pelaksanaan intervensi lingkungan hanya berupa KIE karena puskesmas tidak tersedia dana klinik sanitasi dan tidak ada kerja sama lintas sektor. jika pelaksanaan klinik sanitasi belum sesuai SPO karena disebabkan oleh petugas poliklinik yang lupa merujuk ke klinik sanitasi karena komitmen petugas masih kurang dalam pelaksanaan klinik sanitasi. Intervensi dan inspeksi dilakukan bila diperlukan disebabkan petugas rangkap jabatan, tidak adanya dana dan kendaraan operasional ke lapangan. Intervensi hanya sebatas komunikasi, informasi dan edukasi sedangkan intervensi sarana belum mampu dilakukan disebabkan dana fisik yang tidak ada.
Dalam pelaksanaan klinik sanitasi puskesmas, keterlibatan lintas program diperlukan untuk melancarkan kegiatan klinik sanitasi sehingga tenaga sanitasi berhubungan secara langsung dengan pasien berkat rujukan atau kiriman dari poli umum, poli anak, poli KIA, dan poli usia lanjut. Tenaga sanitasi terus membina hubungan yang baik dengan lintas sektor karena bermanfaat dalam kegiatan intervensi fisik di lapangan. Untuk pelaksanaan klinik sanitasi yang sesuai alur dan pedoman, membutuhkan komitmen dari semua tenaga di puskesmas yang terlibat dalam klinik sanitasi agar benar-benar menjalankan klinik sanitasi sesuai dengan standar yang telah ditetapkan, didukung dengan pengawasan yang dilakukan pimpinan puskesmas terhadap klinik sanitasi. ${ }^{18}$

\section{d. Monitoring dan Evaluasi}

Dinas Kesehatan Kota Jambi tidak pernah datang melakukan monitoring dan evaluasi ke puskesmas mengenai klinik sanitasi. Hal ini disebabkan Dinas Kesehatan Kota Jambi tidak memiliki dana pembinaan khusus untuk klinik sanitasi ke puskesmas. Dinas Kesehatan tidak pernah melakukan umpan balik terhadap laporan klinik sanitasi yang dikirim dari puskesmas disebabkan tenaga sanitasi selalu diingatkan untuk terus mengirimkan laporan kegiatan klinik sanitasi pada setiap pertemuan sanitarian. Pelaksanaan kegiatan klinik sanitasi pada puskesmas pencapaian tinggi menunjukkan bahwa monitoring dan evaluasi dilakukan setiap bulan melalui laporan bulanan.

Kepala puskesmas juga membahas klinik sanitasi pada pertemuan loka karya mini puskesmas karena pimpinan puskesmas benar-benar berkomitmen terhadap pelaksanaan klinik sanitasi, sehingga merasa perlu melakukan monev secara rutin. Hal ini berbeda dengan puskesmas pencapaian rendah yang menunjukkan bahwa monitoring dan evaluasi untuk pelaksanaan kegiatan klinik sanitasinya berupa laporan bulanan dan tidak di bahas dalam loka karya mini puskesmas. Hal ini disebabkan karena kurangnya pemahaman kepala puskesmas bagaimana melaksanakan monitoring dan evaluasi yang dilaksanakan terhadap pelaksanaan klinik sanitasi. ${ }^{18}$ 
Monitoring dan evaluasi (Monev) yang dilakukan selama ini di Puskesmas Pencapaian Rendah belum optimal karena monev yang dilakukan hanya dengan melihat laporan bulanan saja, tanpa melakukan monitoring dan evaluasi melalui pertemuan lokakarya mini di puskesmas karena kurangnya pemahaman kepala puskesmas bagiamana seharusnya melaksanakan monev klinik sanitasi.

Monitoring dan evaluasi kegiatan klinik sanitasi dapat dilakukan dengan turun langsung ke lapangan, laporan bulanan dan dapat juga melalui pertemuan rutin bulanan. Puskesmas mempertahankan dan meningkatkan monitoring dan evaluasi untuk mendapatkan hasil yang lebih maksimal dalam pelaksanaan klinik sanitasi. Kepada Dinas Kesehatan Kota Jambi menganggarkan dana untuk pembinaan pelaksanaan klinik sanitasi ke puskesmas secara berkala dan memberikan penghargaan (reward) bagi pelaksana klinik sanitasi yang terbaik dan memberikan sanksi (punishment) bagi puskesmas yang kurang aktif. Apabila ditemukan masalah atau kendala dalam pelaksanaan klinik sanitasi, tenaga sanitasi dapat segera membahasnya dalam pertemuan rutin. Begitu pula halnya dengan setiap penilaian harus diikuti dengan tindak lanjut agar kegiatan klinik sanitasi berkesinambungan dan dapat bertahan. ${ }^{18}$

\section{Komponen Output}

Puskesmas pencapaian tinggi menunjukkan bahwa keluaran untuk kegiatan pelaksanaan klinik sanitasi belum memperlihatkan hasil sesuai dengan yang diharapkan. Setiap puskesmas telah menentukan target pencapaian setiap awal tahun dan melakukan evaluasi setelah akhir tahun. Setiap puskesmas memiliki keluaran klinik sanitasi berupa target pencapaian yang bervariasi, seperti Puskesmas Simpang Kawat yang secara keseluruhan termasuk dalam puskesmas pencapaian tinggi memiliki cakupan konseling 19,32\%, inspeksi lingkungan mencapai $72,41 \%$, dan intervensi lingkungan sebesar $100 \%$, dan Puskesmas Tanjung Pinang memiliki cakupan konseling 11,05\%, inspeksi lingkungan sudah mencapai 70,33\%, dan intervensi lingkungan 100\%. Begitu pula keluaran yang di dapat puskesmas pencapaian rendah dalam kegiatan pelaksanaan klinik sanitasi yang belum menunjukkan hasil sesuai dengan yang diharapkan. Puskesmas tersebut adalah Puskesmas Aur Duri yang memiliki cakupan konseling 4,92\%, inspeksi lingkungan 38,46\%, dan intervensi lingkungan $100 \%$ dan Puskesmas Paal Lima yang memiliki cakupan konseling 5,43\%, inspeksi lingkungan 35,94\%, dan intervensi lingkungan 100\%.

Perbandingan data keluaran klinik sanitasi pada puskesmas pencapaian tinggi dengan puskesmas pencapaian rendah terlihat dari data cakupan konseling, yaitu puskesmas pencapaian tinggi lebih banyak melakukan konseling dibandingkan dengan puskesmas pencapaian rendah. Dengan demikian, ada hubungan antara data keluaran dan data cakupan konseling. Karena klinik sanitasi pada puskesmas pencapaian rendah dibuka hanya dua kali dalam seminggu dan tenaga sanitasi yang merangkap jabatan, hal ini menyebabkan jumlah pasien yang berkunjung juga sedikit. Selain itu, inspeksi lingkungan yang dilakukan puskesmas pencapaian rendah masih sedikit karena tidak tersedia dana dan kendaraaan operasional sehingga kegiatan inspeksi lingkungan dilakukan mengikuti kegiatan dari program lain. ${ }^{18}$

Pencapaian keluaran klinik sanitasi yang berkualitas, puskesmas perlu melakukan upaya peningkatan dalam pelaksanaan klinik sanitasi. Salah satu adalah dengan mengidentifikasi permasalahan terkait pelaksanaan klinik sanitasi dan mencari solusi terhadap permasalahan tersebut. Upaya perbaikan yang harus dilakukan adalah memenuhi dana, sarana dan prasarana, peningkatan kompetensi tentang klinik sanitasi di puskesmas dan monitoring evaluasi pelaksanaan klinik sanitasi.

Peningkatan hasil pelaksanaan klinik sanitasi adalah meningkatkan komitmen semua pihak yang terlibat dalam klinik sanitasi dan mengevaluasi kinerja tenaga sanitasi kesehatan terkait dengan pelaksanaan klinik sanitasi. Pengawasan dari kepala puskesmas dan Dinas Kesehatan secara terus-menerus untuk kontinuitas pelaksanaan klinik sanitasi. Diharapkan juga ketegasan dari Kepala Dinas Kesehatan untuk melakukan penilaian kinerja terhadap semua kepala puskesmas terhadap pencapaian pelaksanaan klinik sanitasi karena setiap pencapaian program yang berada di bawah tugas pokok dan fungsi kepala puskesmas yang merupakan tanggung jawabnya. ${ }^{16}$ 


\section{SIMPULAN}

Tenaga sanitasi yang berada di puskesmas pencapaian tinggi dan pencapaian rendah belum pernah mendapatkan pelatihan klinik sanitasi. Pada perencanaan anggaran dana puskesmas pencapaian tinggi mendapatkan dana BOK sedangkan puskesmas pencapaian rendah tidak ada. Plan of action (POA) puskesmas pencapaian tinggi terdapat kegiatan klinik sanitasi sedangkan puskesmas pencapaian rendah tidak ada. Puskesmas pencapaian tinggi telah melaksanakan monitoring dan evaluasi melalui laporan dan lokakarya mini puskesmas, sedangkan puskesmas pencapaian rendah hanya dilakukan melalui laporan.

Target yang telah dicapai oleh puskesmas pencapaian tinggi adalah cakupan intervensi lingkungan, sedangkan target yang belum tercapai adalah cakupan konseling dan inspeksi lingkungan. Begitu pula yang dialami puskesmas pencapaian rendah, yaitu target cakupan intervensi lingkungan telah tercapai, tetapi target cakupan konseling dan inspeksi lingkungan belum tercapai.

\section{SARAN}

Dinas Kesehatan Kota Jambi dan Kepala Puskesmas diharapkan untuk meningkatkan komitmen bagi semua tenaga kesehatan yang terlibat, melakukan perencanaan terhadap penempatan dan kualifikasi pegawai, mengadakan pelatihan, memfasilitasi sarana dan prasarana puskesmas, mengusulkan dan menganggarkan dana untuk kegiatan, membina dan mengawasi secara rutin dan berkala terhadap pelaksanaan kegiatan klinik sanitasi, dan memberikan penghargaan (reward) untuk pegawai yang berprestasi.

\section{UCAPAN TERIMA KASIH}

Terima kasih peneliti sampaikan kepada seluruh pihak yang turut membantu dalam menyelesaikan penelitian ini.

\section{DAFTAR PUSTAKA}

1. Peraturan Pemerintah No.66 Tahun 2014 tentang Kesehatan Lingkungan. Jakarta; 2014.
2. World Health Organization (WHO). Global health risks: mortality and burden of disease attributable to selected major risk. Geneva: WHO Press; 2009.

3. Dinas Kesehatan Provinsi Jambi. Profil dinas kesehatan provinsi Jambi tahun 2017. Jambi: Dinas Kesehatan Provinsi Jambi; 2018.

4. Dinas Kesehatan Kota Jambi. Profil dinas kesehatan kota Jambi tahun 2017. Kota Jambi: Dinas Kesehatan Kota Jambi; 2018.

5. Kementerian Kesehatan RI. Peraturan menteri kesehatan RI nomor 13 tahun 2015 tentang penyelenggaraan kesehatan lingkungan di puskesmas. Jakarta: Kementerian Kesehatan RI; 2015.

6. Sugiyono. Metode penelitian kuantitatif, kualitatif dan R\&D. Bandung: Alfabeta; 2014.hlm.58-82.

7. Kementerian Kesehatan RI. Peraturan menteri kesehatan nomor 75 tahun 2014 tentang puskesmas. Jakarta: Kementerian Kesehatan RI; 2014.

8. Departemen Kesehatan RI. Pedoman teknis klinik sanitasi untuk puskesmas. Jakarta: Departemen Kesehatan RI; 2002.

9. Departemen Kesehatan RI. Standar prosedur operasional dan panduan konseling klinik sanitasi. Jakarta: Departemen Kesehatan RI; 2008.

10. Departemen Kesehatan RI. Panduan konseling bagi petugas klinik sanitasi di puskesmas. Jakarta: Departemen Kesehatan RI; 2001.

11. Hasibuan M. Manajemen sumber daya manusia, Edisi Revisi. Jakarta: PT Bumi Aksara. 2005; 75102.

12. Kementerian Kesehatan RI. Pedoman pelaksaanaan klinik sanitasi. Jakarta: Kementerian Kesehatan RI; 2013.

13. Jamarin V. Gambaran pelaksanaan klinik sanitasi di puskesmas Bukit Tinggi. Jurnal Kesehatan Andalas. 2016;5(1):154-7.

14. Ayuningtyas D. Kebijakan kesehatan: prinsip dan praktik. Jakarta: PT Raja Grafindo Persada. 2014.hlm. 45-61.

15. Sari E. Analisis sumber daya organisasi dalam pelaksanaan program klinik sanitasi puskesmas di kabupaten Padang Pariaman tahun 2012 [artikel penelitian]. Padang: Universitas Andalas. 2012; 21-8. 
16. Putri AM, Mulasari SA. Klinik sanitasi dan perannya dalam peningkatan kesehatan lingkungan di puskesmas Pajangan Bantul. Jurnal Medika Respati. 2018;13(2):01-9.

17. Nandiabltamar A, Megiddoac A, Ashvin A. Reduced burden of childhood diarrheal diseases through increased access to water and sanitation in India: a modeling analysis. Journal Social Science \& Medicine. 2017;180(7):181-92.

18. Wardani RWK. Evaluasi pelaksanaan program klinik sanitasi di puskesmas (pelayanan kesehatan lingkungan di puskesmas) bagi penderita tuberkulosis paru BTA (+) di Kabupaten Nganjuk [tesis]. Surabaya: Universitas Airlangga; 2017. 